\title{
POTRET EFEKTIVITAS PELAKSANAAN CORPORATE SOCIAL RESPONSIBILITY (CSR) OLEH PT. PERTAMINA (PERSERO) MARKETING OPERATION REGION (MOR) I - TERMINAL BAHAN BAKAR MINYAK (TBBM) TELUK KABUNG MELALUI PROGRAM BANGUN INDUSTRI DESA (BID) BISNIS PERIKANAN DI KECAMATAN BUNGUS TELUK KABUNG KOTA PADANG
}

\author{
Faisal $^{1}$, Stelly Martha Lova ${ }^{2}$, Lala Jelita Ananda ${ }^{1}$ \\ ${ }^{1}$ Fakultas Ilmu Pendidikan, Universitas Negeri Medan, Medan, Indonesia \\ ${ }^{2}$ Fakultas Ilmu Pendidikan, Universitas Negeri Padang, Padang, Indonesia \\ * Penulis Korespondensi: faisalpendas@ gmail.com
}

\begin{abstract}
Abstrak
Pengembangan Bangun Industri Desa (BID) oleh PT. Pertamina (Persero) MOR I - TBBM Teluk Kabung memfokuskan pada peningkatan daya saing bisnis hasil olahan laut terutama ikan dan kerang yang dihasilkan oleh masyarakat nelayan di Teluk Kabung Utara. Studi ini menganalisis secara kualitatif mengenai capaian dari pelaksanaan CSR dalam mengatasi permasalahan rendahnya pemahaman dan kemampuan nelayan dalam melakukan bisnis perikanan. Bisnis ini mempunyai peluang besar dalam meningkatkan kesejahteraan masyarakat nelayan. Metode yang dilakukan dalam program ini antara lain: (1) analisis penyedia bahan baku, (2) analisis tenaga kerja, (3) analisis ragam kuliner (olahan jadi), (4) desain miniplant bisnis perikanan, dan (5) analisis peluang pangsa pasar. Dengan metode ini diharapkan paradigma dan kemampuan masyarakat nelayan dalam mengelola bisnis perikanan semakin maju dan berkembang. Hasil pendampingan menunjukkan bahwa masyarakat Kecamatan Bungus Teluk Kabung Kota Padang telah mampu menghasilkan beragam olahan makanan ringan dan snack yang berasal dari ikan dan kerang serta dikembangkan dalam bentuk bisnis keluarga sederhana. Dengan demikian, program pendampingan BID berupa fasilitasi bisnis perikanan di Kecamatan Bungus Teluk Kabung dapat dijadikan rujukan dan pengembangan lebih lanjut di berbagai daerah terutama pinggiran pantai sebagai upaya meningkatkan kesejahteraan masyarakat yang ada di sekitarnya.
\end{abstract}

Kata Kunci: Bangun Industri Desa (BID), Olahan Boga Bahari, Pemberdayaan Masyarakat Nelayan, Teluk Kabung Utara

\begin{abstract}
The aim of developing The Village Industrial Development (abbreviated as BID) facilitated by PT. Pertamina (Persero) MOR I - TBBM Teluk Kabung is to improve the business competitiveness of marine processed products, especially fish and shellfish produced by fishing communities in the Teluk Kabung Utara. This study qualitatively analyzes achievements of CSR implementation in overcoming relvant problems of low understanding and ability of fishermen in managing fisheries business. This business has a great potential however in boosting the welfare of fishing communities with good facilitations and approaches provided by relevant experts. The methods used in this program include: (1) analysis of raw material providers, (2) analysis of labor, (3) analysis of culinary variety (finished processing), (4) design of fisheries business miniplant, and (5) analysis of share opportunities market. It is expected that the paradigm and capability of the fishing community in managing the fisheries business will be more advanced and developing. The outcomes indicated that local people of Bungus Teluk Kabung Subdistrict in Padang City have been able to produce various processed snacks and snacks derived from fish and shellfish enhancing a more professional small family business management. Thus, the BID mentoring program in facilitating of fisheries business in Bungus Teluk Kabung Subdistrict can be used as a reference to be further developed in various areas, especially coastal areas as an effort to improve the welfare of the fisheries communities.
\end{abstract}

Keywords: Village Industry Development (BID), Marine Processed Products, Fisheries Community Empowerment, Teluk Kabung Utara 


\section{PENDAHULUAN}

Merujuk pada World Development Report (2003), penduduk miskin di daerah berhadapan dengan beberapa tantangan yang mempengaruhi pembangunannya. Tantangan tersebut antara lain: (1) terbatas bahkan rusaknya sumber daya alam, (2) terbatasnya infrastruktur (transportasi, komunikasi, kesehatan, pendidikan, air bersih, dan listrik), dan (3) terbatasnya kesempatan ekonomi lokal. Di mana semua itu menjadi penghalang masyarakat desa dari kegiatan ekonomi riil.

Berdasarkan konsep pembangunan (berbasis masyarakat) diketahui bahwa keberhasilan pembangunan masyarakat perlu dilihat dari beberapa modal komunitas (community capital) yang terdiri dari: (a) modal manusia (human capital) berupa kemampuan personal seperti pendidikan, pengetahuan, kesehatan, keahlian, dan keadaan terkait lainnya; (b) modal sumber daya alam (natural capital) seperti perairan laut; (c) modal ekonomi produktif (produced economic capital) berupa aset ekonomi dan finansial serta aset lainnya; dan (d) modal sosial (sosial capital) berupa norma/nilai (trust, reciprocity, norma sosial lainnya), partisipasi dalam jaringan, dan pro-activity (Hasbullah, 2006).

Masyarakat wilayah pesisir yang berprofesi sebagai nelayan hingga kini masih merupakan salah satu pelaku usaha perikanan yang berkontribusi besar terhadap masih tingginya tingkat kemiskinan masyarakat di wilayah pesisir. Dari 8090 desa pesisir yang sebagian besar dihuni masyarakat nelayan, tercatat 16,42 juta jiwa hidup dengan indeks kemiskinan sebesar 0,32. Artinya lebih kurang $32 \%$ individu di wilayah pesisir masih belum mampu memenuhi kebutuhan hidup yang mendasar (Pontoh, 2010).

Citra kemiskinan nelayan itu sesungguhnya suatu ironi, mengingat Indonesia memiliki wilayah laut yang sangat luas, bahkan lebih luas dari pada wilayah darat. Di dalam wilayah laut juga terdapat berbagai sumber daya yang memiliki potensi ekonomi tinggi, yang semestinya dapat dimanfaatkan untuk menjamin kesejahteraan hidup nelayan dan keluarganya. Kondisi yang dialami nelayan tentunya sangat memprihatinkan, karena nelayan merupakan ujung tombak pengelola perikanan di Indonesia.

Mengingat laju pertumbuhan penduduk yang terus meningkat, sehingga lahan di daratan akan dirasakan semakin sempit, maka mata pencarian sebagai nelayan diharapkan menjadi tumpuan harapan di masa depan. Untuk itu, di masa depan masyarakat secara berangsurangsur diharapkan terdorong untuk mengalihkan kegiatan ekonominya ke arah laut.

Adanya kemiskinan yang dialami oleh nelayan, pengalihan kegiatan ekonomi ke laut dikhawatirkan sulit terjadi, sebab para anak nelayan pun dikhawatirkan tidak tertarik lagi untuk menekuni pekerjaan kenelayanan. Jika hal itu terjadi, kegiatan di darat akan semakin padat, sedangkan laut yang memiliki nilai ekonomi tinggi akan terabaikan. Akibatnya potensi ekonomi yang terkandung di dalamnya akan sia-sia (Imron, 2003). Padahal, wilayah pesisir memiliki arti strategis karena merupakan wilayah peralihan (interface) antara ekosistem darat dan laut yang mempunyai potensi sumber daya alam dan jasa-jasa lingkungan yang sangat kaya (Sutrisno, 2014).

Gambaran kondisi di atas merupakan realitas yang juga dialami oleh masyarakat nelayan di Teluk Kabung Utara, Kecamatan Bungus Teluk Kabung, Kota Padang. Warga Teluk Kabung Utara mengeluhkan rendahnya harga jual hasil tangkapan ikan. Rendahnya harga hasil panen para nelayan dikarenakan masih minimnya pengetahuaan pengolahan dan marketing. Selain itu cara menjalankan usaha perikanan yang dilakukan oleh nelayan masih tergolong tradisional. Jika dilihat dari sisi skala usaha perikanan, kelompok masyarakat pesisir Teluk Kabung Utara di antaranya terdiri dari rumah tangga perikanan yang menangkap ikan tanpa menggunakan perahu, menggunakan perahu tanpa motor, dan perahu bermotor tempel. Dengan skala usaha ini, rumah tangga ini hanya mampu menangkap ikan di daerah dekat pantai. Dalam kasus tertentu, memang mereka dapat pergi jauh dari pantai dengan cara bekerjasama sebagai mitra perusahaan besar. Namun, usaha dengan hubungan kemitraan seperti tidak begitu banyak dan berarti dibandingkan dengan jumlah rumah tangga yang begitu banyak (Nikijuluw, 2001).

Permasalahan lain yang dihadapi adalah para istri nelayan umumnya tidak mempunyai pekerjaan yang dapat membantu meningkatkan pendapatan keluarga. Para isteri ini lebih disibukkan dengan peran domestiknya sebagai ibu rumahtangga karena tidak atau kurang memiliki keterampilan khusus yang bisa digunakan untuk menambah penghasilan suaminya sebagai nelayan. Meskipun demikian, tidak sedikit isteri nelayan turut berkontribusi pada pekerjaan suaminya untuk memasarkan ikan hasil tangkapan yang diperoleh suaminya (Wasak, 2012).

Menyikapi persoalan di atas, berbagai program pengentasan kemiskinan atau peningkatan kesejahteraan masyarakat sebenarnya telah banyak diluncurkan. Demikian pula yang menyentuh masyarakat nelayan dan masyarakat pesisir lainnya. Namun, hasilnya belum sesuai dengan harapan. Salah satu penyebabnya adalah kurang tepatnya sasaran program karena indikator yang digunakan dalam menentukan sasaran kurang akurat. Oleh karenanya, penggunaan indikator penetapan sasaran yang tepat yaitu sesuai dengan tujuan program sangat diperlukan untuk menentukan sasaran program (Muflikhati, et al., 2010)

Upaya mendukung dan mengentaskan permasalahan warga Teluk Kabung Utara dalam meningkatkan kesejahteraan masyarakatnya, CSR PT. Pertamina 
(Persero) MOR I - TBBM Teluk Kabung mendesain satu model pemberdayaan masyarakat yang disebut dengan model klaster berdaya yang berkonsentrasi pada Bangun Industri Desa (BID). Dedikasi TBBM Teluk Kabung dalam menumbuhkembangkan sektor ekonomi produktif di kawasan operasionalnya merupakan pemenuhan capaian tata kelola perusahaan yang baik sesuai dengan amanah Peraturan Menteri Negara BUMN No. PER-05/MBU/2007 tentang program kemitraan Badan Usaha Milik Negara (BUMN) dengan usaha kecil dan program bina lingkungan dan UU No.22 Tahun 2001 tentang pertanggungjawaban BUMN energi dalam pengembangan lingkungan dan masyarakat setempat.
Pada tahun 2017, pengembangan dan penetapan Klaster Berdaya di Teluk Kabung Utara difokuskan pada terbentuknya Fasilitasi Bisnis Perikanan melalui program kelompok pengolah dasar hasil perikanan.

\section{METODE PELAKSANAAN KEGIATAN}

Program pendampingan dilakukan dengan beberapa tahapan, antara lain: (1) analisis penyedia bahan baku, (2) analisis tenaga kerja, (3) analisis ragam kuliner (olahan jadi), (4) desain miniplant bisnis perikanan, dan (5) analisis peluang pangsa pasar. Secara sederhana skema bisnis perikanan melalui Bina Industri Desa dapat dilihat pada Gambar 1 berikut.

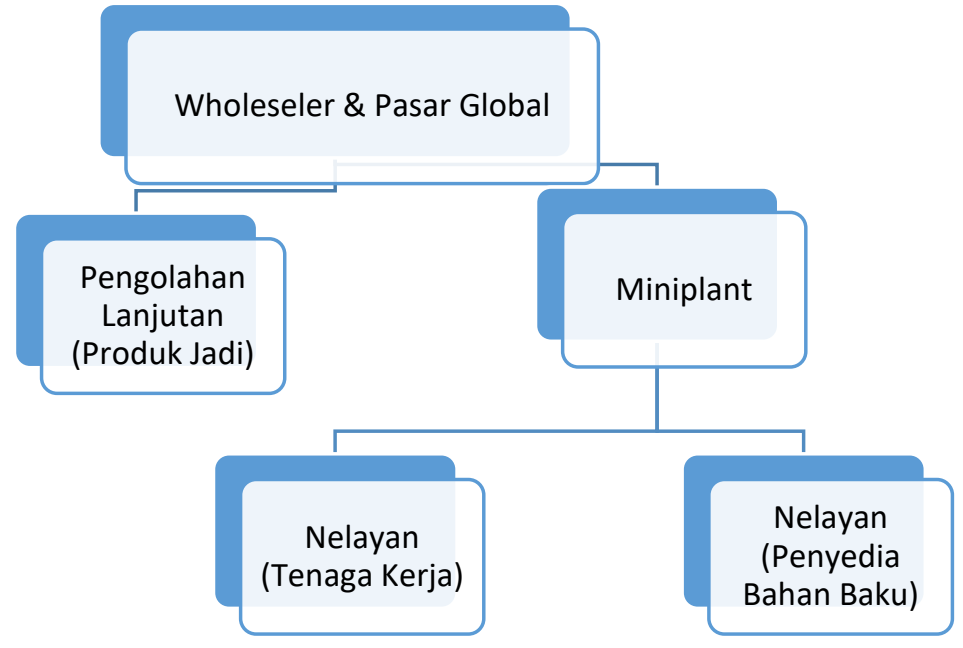

Gambar 1. Skema Bina Industri Desa

Berdasarkan Gambar 1 di atas, dapat diuraikan lebih lanjut sebagai berikut:

\section{Analisis Penyedia Bahan Baku}

Analisis ini bertujuan untuk mengetahui ketersediaan dan penyedia bahan baku. Hal ini dilakukan untuk mempermudah memperoleh bahan baku sehingga produksi keluarga tidak terhambat karena keterbatasan bahan baku. Ketersediaan bahan baku juga berpengaruh terhadap cost produksi. Dengan demikian, harga modal tidak terlalu tinggi sehingga bisa disesuaikan dengan harga di pasaran dengan produk yang sama, bahkan lebih murah.

\section{Analisis Tenaga Kerja}

Analisis ini dilakukan untuk melihat peluang tenaga kerja yang bisa dijadikan personil pada bisnis perikanan yang akan dibentuk. Hal ini juga bertujuan untuk mengurangi pengangguran bagi masyarakat nelayan dan dapat meningkatkan kesejahteraan keluarga. Tenaga kerja pada bisnis perikanan bisa dilakukan langsung oleh para nelayan, istri-istri nelayan, dan anakanaknya secara langsung tanpa harus menggaji tenaga kerja lain. Dengan demikian, biaya produksi menjadi menurun dan berpengaruh terhadap harga jual hasil produksi.

\section{Analisis Ragam Kuliner (Olahan Jadi)}

Analisis ragam kuliner hasil olahan laut juga perlu dipertimbangkan. Ragam ini bertujuan untuk menarik minat konsumen dalam memperoleh kuliner yang beragam, baik yang akan dikonsumsi secara langsung, maupun dijadikan sebagai oleh-oleh ketika bepergian.

\section{Desain Miniplant Bisnis Perikanan}

Desain miniplant bisnis perikanan perlu dipertimbangkan agar pelaksanaan program bisnis perikanan dapat dilakukan secara sederhana, namun terprogram dan mempunyai output yang jelas.

\section{Analisis Peluang Pangsa Pasar}

Analisis peluang pangsa pasar perlu dilakukan untuk mengetahui para konsumen pengguna produk yang dihasilkan, baik digunakan secara langsung maupun digunakan sebagai oleh-oleh keluarga. Dengan demikian, produk yang dihasilkan tidak menumpuk begitu saja namun dapat didistribuasikan dengan baik dalam bentuk penjulan kepada para konsumen.

\section{HASIL KEGIATAN DAN PEMBAHASAN}

Bangun Industri Desa (BID) adalah suatu program pemberdayaan masyarakat yang bertujuan untuk meningkatkan taraf hidup masyarakat dan pembangunan ekonomi berbasis potensi lokal. Program ini dijalankan melalui pengembangan potensi lokal 
yang dimiliki daerah tersebut dengan cara membangun sebuah usaha kelompok pengelola produk unggulan lokal guna meningkatkan nilai jual yang lebih tinggi.

BID berusaha menjawab beberapa permasalahan yang dihadapi oleh masyarakat daerah pedesaan, di antaranya: (1) keterbatasan dalam permodalan, fasilitas, dan pengetahuan tentang pengembangan produk hingga mampu meningkatkan nilai jual produk, (2) keterbatasan managerial suatu unit usaha kecil dalam menghadapi tantangan pasar, dan (3) kemampuan membangun jaringan.

Program Bangun Industri Desa (BID) yang telah dilakukan dalam menjawab permasalahanpermasalahan di atas dilakukan dengan 4 tahapan intervensi, antara lain:

\section{1) Pembentukan Kelembagaan Usaha}

Kelembagaan usaha yang dibentuk adalah Usaha Kecil Menengah (UKM) yang didampingi untuk disahkan oleh pemerintahan setempat. Kegiatan yang dilakukan untuk pembentukan UKM ini antara lain sosialisasi kepada stakeholder terkait, perekrutan pengurus UKM, pelatihan organisasi, dan manajemen industri desa, serta perumusan program kerja organisasi. Kelembagaan usaha terdiri dari kelompok penyedia bahan baku, kelompok produksi olahan, dan kelompok pemasar. Kelembagaan usaha dibentuk pada awal program guna mengelola pembagian peran yang jelas dalam kelompok usaha sehingga setiap individu akan mendapatkan pelatihan keterampilan usaha sesuai dengan perannya masing-masing.

\section{2) Pembuatan Perencanaan Bisnis}

Perencanaan bisnis yang dibuat menggunakan Business Model Canvas (BMC) dan Biaya Harga Pokok Kelompok (BHP). UKM telah diberikan pelatihan mengenai BMC dan BHP sebelum membuat perencanaan bisnis kelompok. BMC dan BHP tersebut kemudian menjadi acuan proses implementasi usaha kelompok.

\section{3) Pembangunan Miniplant}

Miniplant atau rumah produksi dibangun berdasarkan BMC dan BHP yang dibuat kelompok. Miniplant ini didirikan setelah BMC dan BHP memenuhi syafat kelayakan usaha. Setelah miniplant dibangun, kelompok diberikan pelatihan keterampilan teknis pengolahan bakan baku secara profesional menjadi pangan olahan, pelatihan SOP produksi untuk menjadi standarisasi kualitas produk, dan pelatihan P-IRT untuk memastikan seluruh elemen dan proses produksi memenuhi persyaratan dalam izin P-IRT. Pelatihan ini berlangsung paralel dengan proses produksi dan pemasaran.

\section{4) Produksi dan Pemasaran}

Proses produksi dan pemasaran dijalankan setelah miniplant selesai dibangun. Selama proses produksi dan pemasaran, penerima manfaat mendapat pembinaan mengenai pencatatan produksi dan pemasaran. Pendampingan juga dilakukan selama proses produksi dan pemasaran. Secara sederhana, proses pelaksanaan program BID dapat dilihat pada Gambar 2 berikut.

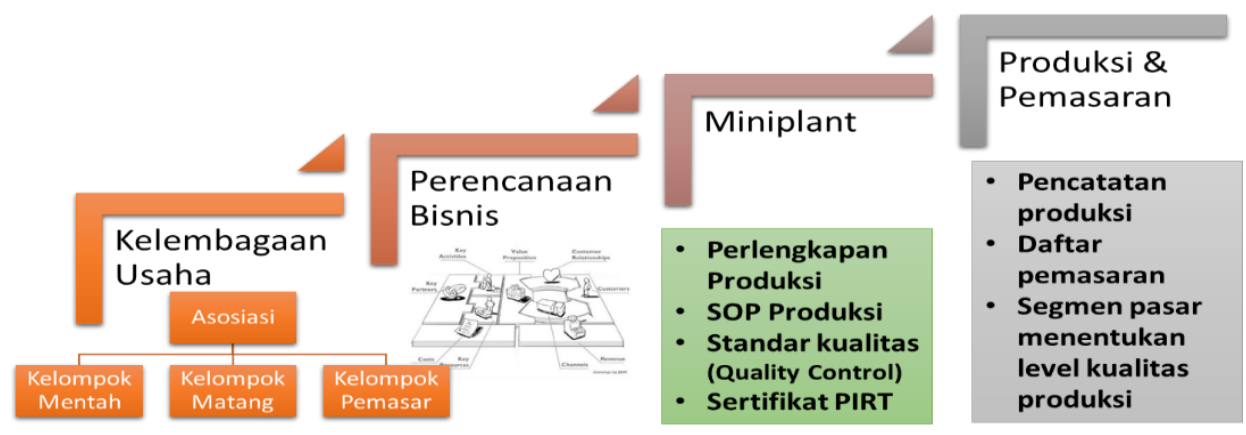

Gambar 2. Skema Program BID

Program Bangun Industri Desa (BID) dapat dikatakan mendukung Sustainable Development Goals point ke satu, yaitu no poverty dan ke delapan, yaitu good jobs and economic growth. Hal ini karena keluaran dari program BID adalah peningkatan kapasitas masyarakat dalam menghasilkan nilai tambah dari produk unggulan lokal sehingga masyarakat mengalami peningkatan penghasilan. 

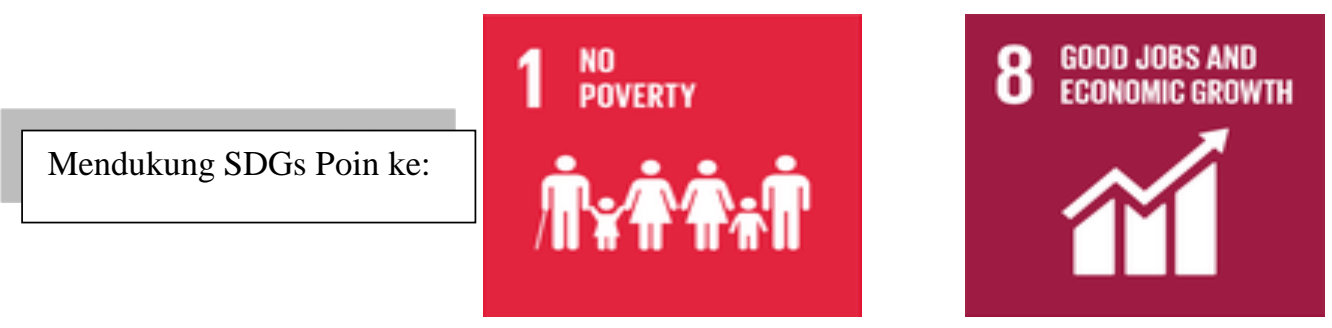

Gambar 3. Indikator SDGS Point $1 \& 8$

Program ini juga diperkuat oleh proses pembinaan dan pendampingan intensif. Proses pendampingan dilakukan di sepanjang proses produksi dan pemasaran. Proses pendampingan menekankan pada kualitas produk, target kuantitas produk dan packaging produk. Pada bidang pemasaran proses pendampingan dilakukan untuk memantau pembukaan pasar dan target titik yang harus dicapai dalam kurun waktu satu tahun. Proses pembinaan dilakukan setiap dua pekan sekali, materi yang diberikan pada proses pembinaan disesuaikan dengan kurikulum yang telah disusun.

Program Fasilitasi Bisnis Perikanan oleh PT. Pertamina (Persero) MOR I - TBBM Teluk Kabung berjalan selama enam bulan dan sudah didampingi hingga tahap pembuatan produk olahan perikanan. Saat ini kelompok yang didampingi, yaitu Srikandi Nusantara sudah mendapatkan SK dari pihak kelurahan dan sedang mengurus POKLASAR di dinas Perikanan dan Kelautan Kota Padang. Berikut beberapa gambaran tema materi yang telah disampaikan pada proses pembinaan pada kelompok Srikandi Nusantara, antara lain:
Tabel 1. Daftar Materi Pembinaan

\begin{tabular}{|c|c|c|}
\hline No & Tema & $\begin{array}{l}\text { Frekuensi } \\
\text { (Kali) }\end{array}$ \\
\hline 1 & Penerapan keuangan sederhana & 2 \\
\hline 2 & $\begin{array}{l}\text { Standard operational procedure } \\
\text { (SOP) produksi dan pemasaran }\end{array}$ & 3 \\
\hline 3 & $\begin{array}{l}\text { Praktik pembuatan MBK dan } \\
\text { BHP }\end{array}$ & 2 \\
\hline 4 & $\begin{array}{l}\text { Praktik pengembangan produk } \\
\text { olahan }\end{array}$ & 3 \\
\hline 5 & Pelatihan pemasaran & 2 \\
\hline 6 & $\begin{array}{l}\text { Kepemimpinan dan public } \\
\text { speaking }\end{array}$ & 1 \\
\hline 7 & Penataan Miniplant & 1 \\
\hline 12 & $\begin{array}{l}\text { Sertifikasi } \\
>\text { PIRT dan Halal jika produk } \\
\text { makanan } \\
>\text { SNI jika produk non } \\
\text { makanan }\end{array}$ & 1 \\
\hline 13 & $\begin{array}{l}\text { Pelatihan manajemen } \\
\text { pengelolaan UMKM }\end{array}$ & 1 \\
\hline 14 & $\begin{array}{l}\text { Studi banding pada jenis usaha } \\
\text { sejenis }\end{array}$ & 2 \\
\hline 15 & $\begin{array}{l}\text { Membangun kemitraan dan } \\
\text { jaringan }\end{array}$ & 2 \\
\hline
\end{tabular}

Adapun produk-produk yang diproduksi oleh kelompok berbahan baku tuna. Seperti; stik tuna, nugget tuna, mpek-mpek tuna, brownis tuna dan akan divariasikan nantinya. Secara sederhana gambaran produk hasil olahan ikan oleh kelompok Srikandi Nusantara dapat dilihat ada Gambar 4 berikut.
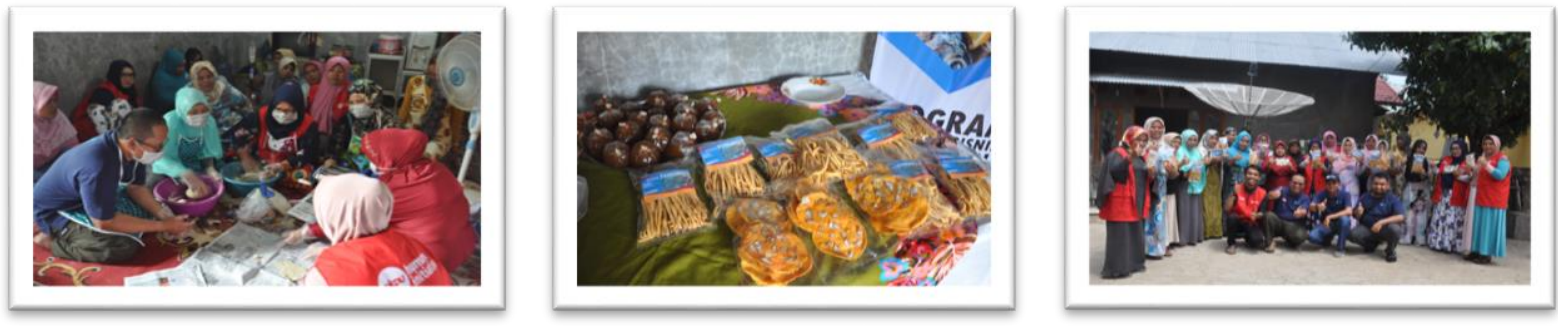

Gambar 4. Kegiatan Pendampingan Kuliner dan Produk Hasil Olahan

Berdasarkan hasil program pendampingan dan pembinaan, kelompok Srikandi Nusantara telah mampu mengembangkan ragam kuliner dari hasil olahan ikan. Kelompok ini juga telah menjadi UKM baru yang dapat meningkatkan kesejahteraan keluarga. Dengan demikian, program Bina Industri Desa (BID) oleh PT.
Pertamina (Persero) MOR I - TBBM Teluk Kabung telah berjalan dengan baik dan sesuai harapan.

\section{KESIMPULAN}

Program Fasilitasi Bisnis Perikanan oleh PT. Pertamina (Persero) MOR I - TBBM Teluk Kabung berjalan 
dengan baik dan sesuai harapan. Beberapa hasil kegiatan yang telah diperoleh berdasarkan pelaksanaan program BID antara lain: (1) peningkatan pengelolaan keungan sederhana, (2) diperolehnya rumusan SOP produksi dan pemasaran, (3) peningkatan kemampuan membuat MBK dan BHP, (4) peningkatan kemampuan dalam pemasaran, (5) diperoleh SK dari pihak kelurahan dan sedang mengurus POKLASAR di dinas Perikanan dan Kelautan Kota Padang, (6) peningkatan manajemen UMKM, dan (7) meningkatkan kemitraan dan jaringan. Dengan demikian, program BID yang dilakukan oleh PT. Pertamina (Persero) MOR I TBBM Teluk Kabung sangat membantu meningkatkan kesejahteraan masyarakat nelayan.

\section{DAFTAR PUSTAKA}

Hasbullah, J. 2006. Social Capital (Menuju Keunggulan Budaya Manusia Indonesia). Jakarta: MR- United Press.

Imron, Masyuri. "Kemiskinan dalam Masyarakat Nelayan." Jurnal Masyarakat dan Budaya 5.1 (2003): 63-82.

Muflikhati, Istiqlaliyah, et al. "Kondisi Sosial Ekonomi dan Tingkat Kesejahteraan Keluarga: Kasus Di Wilayah Pesisir Jawa Barat." Jurnal Ilmu Keluarga \& Konsumen 3.1 (2009): 1-10.

Nikijuluw, Victor PH. "Populasi dan Sosial Ekonomi Masyarakat Pesisir Serta Strategi Pemberdayaan Mereka dalam Konteks Pengelolaan Sumberdaya Pesisir Secara Terpadu." Bogor (ID): Pusat Kajian Sumberdaya pesisir dan lautan, Institut Pertanian Bogor (2001).

Pontoh, Otniel. "Identifikasi dan Analisis Modal Sosial dalam Rangka Pemberdayaan Masyarakat Nelayan Desa Gangga Dua Kabupaten Minahasa Utara." Jurnal Perikanan dan Kelautan Tropis 6.3 (2010): 125-133.

Sutrisno, Endang. "Implementasi Pengelolaan Sumber Daya Pesisir Berbasis Pengelolaan Wilayah Pesisir Secara Terpadu untuk Kesejahteraan Nelayan (Studi di Perdesaan Nelayan Cangkol Kelurahan Lemahwungkuk Kecamatan Lemahwungkuk Kota Cirebon)." Jurnal Dinamika Hukum 14.1 (2014): 1-12.

Wasak, Martha P. "Keadaan Sosial-Ekonomi Masyarakat Nelayan dl Desa Kinabuhutan Kecamatan Likupang Barat. Kabupaten Minahasa Utara, Sulawesi Utara." Pasific Journal3.5 (2010): 958-962. 